\title{
レーザー回折・散乱法における入力光学特性値が 粒子径分布測定結果に及ぼす影響
}

\author{
早川 修, 安田 佳 弘** \\ 内 藤 牧 男*, 椿 淳 一 郎***
}

\begin{abstract}
The Effect of the Refractive Index Input
Value on Particle Size Distribution Measured by the Laser Diffraction \& Scattering Method
\end{abstract}

by

\author{
Osamu HAYAKAWA ${ }^{\dagger}$, Yoshihiro YASUDA ${ }^{\dagger \dagger}$, \\ Makio NAITO ${ }^{\dagger}$ and TSUBAKI JunIchiro ${ }^{\dagger \dagger}$
}

\begin{abstract}
A method for estimating the optimum refractive index input value was established to decrease the scattering of the measured results that come with different equipment using the laser diffraction and scattering method.

The effect of the imaginary part of the refractive index input value in this estimation method was discussed with copper as the absorbing material and polystyrene, alumina as the non-absorbing material, respectively. For the copper powders which have a large value in the imaginary part, the scattering of the results was decreased with the optimum refractive index input value which is obtained when considering both the real and imaginary parts in this estimation method. For polystyrene and alumina powders which have a small value in their imaginary part, the optimum refractive index input value was obtained when the imaginary part was 0 .

On the other hand, the estimation method consists of some problems when measuring a bimodal sample. The validity of this estimation method was discussed for the bimodal sample of mono dispersed silica.
\end{abstract}

Key Words : Particle Size Analysis, Laser Diffraction \& Scattering, Refractive Index, Imaginary Part, Bimodal Sample

\section{1. 緒言}

ファインセラミックスをはじめとする，サブミクロ ン粒子の粒子径分布測定装置の主流となっているレ一
ザ一回折・散乱法は，測定の際，粒子屈折率を光学特 性值として装置に入力する必要がある。そのため本測 定法では，これまで粒子屈折率未知の試料では正しい 測定ができなかった。また粒子屈折率が既知であって

$\dagger$ Japan Fine Ceramics Center, Res. and Development Lab. (2-4-1 Mutsuno, Atsuta-ku, Nagoya 456)

†† KANEFUSA Corp. (1-1 Nakakoguchi, Ohguchi-cho, Niwa-gun. Aichi 480-01)

†† Dept. of Micro-system Eng., Grad. School of Nagoya Univ. (Furo-cho, Chikusa-ku Nagoya 464-01)
化学工学会第27回秋季大会(1994年 9月, 春日井)にて発表

*（財)ファインセラミックスセンタ一試験研究所 (†456 名古屋市熱田区六野 2丁目 4-1)

TEL. $052-871-3500$

**兼房(株) ( TEL. $0587-95-2821$

**名古屋大学大学院工学研究科マイクロシステム工学専攻 ( T464-01 名古屋市千種区不老町)TEL. 052-789-5030 
も, 妥当な結果が得られないことがあり, しかも複数 の機種で得られた分布を比較した場合，必ずしも結果 が一致しないという問題点があった。著者らは前報1に て,このようなレーザー回折・散乱法の問題点を解決 する最適入力光学特性值の推定法について報告し た。本推定法で得られた最適値を用いると、ファイン セラミックス粒子の場合には屈折率未知試料の測定が 可能となり，機種間の整合性および測定結果の確度が 向上した。

ところでレーザー回折・散乱法で光学特性值として 入力する粒子屈折率は, 光の屈折を表わす実数部と, 消衰を表わす虚数部からなる。屈折率虚数部は物質の 電気伝導率に関係し2)，一般にバルク体の場合，金属 では大きい值を，またファインセラミックスのような 非金属物質では $10^{-4}$ 程度の 0 に近い非常に小さな值を 持つと言われる3)。前報1)ではファインセラミックス 粒子のみを对象としたため, 虚数部に関しては 0 とし て扱い, 実数部のみを対象として最適入力光学特性值 を推定した。しかしながら，レーザ一回折・散乱法で 測定対象となる粒子の種類は様々である。例えば金属 粒子の測定においては, 屈折率虚数部の影響が無視で きないと思われる。更に実際の粒子では，消衰係数が 表面性状の影響等によりバルク体より大きくなるとい う報告 ${ }^{4}$ もある。このため非金属物質といえども，虚 数部に 0.1 程度の值の入力を推奨する装置もあるが, 虚数部の入力值が定量的に議論された例は見当たらな い。屈折率虚数部の值は, 文献にも限られたものしか 載っておらず，その取扱いには未だ不明な点が多い。 そのため現在市販されている装置の半数以上にあたる 8 機種で, 光学特性值の虚数部に值を入力できるよう になってはいるが, 実際には入力值を決めかねている のが現状である。

そこで本報では，ファインセラミックス粒子とは光 学的特性が異なる金属粒子を用い, 前報で提案した最 適入力光学特性值の推定法を実数部に加えて虚数部に も適用することにより，機種間の整合性がどの程度向 上するか検討を行った。加えて金属とは材質が異な り, 屈折率虚数部の值が非常に小さいといわれる樹脂 粒子，および前報では実数部だけの検討に留まってい たファインセラミックス粒子に対しても，実数部に加 え屈折率虚数部の影響について検討を行った。

更に,レーザ一回折・散乱法ではバイモーダル試料 を測定した場合，一般にバイモーダル性が現われにく い等といった問題点がある。前報 ${ }^{1)}$ では単一分布の試 料のみを用いたため, 測定に高い分解能が要求される
バイモーダルの分布を持つ試料に対しては，本推定法 の有効性は未だ明らかになっていない。そこで本研究 では，バイモーダル試料に対しても本推定法が正確な バイモーダル性を得る上で効果があるか若干の検討を 行った。

\section{2. 実験試料，装置および試料調製法}

試料には, ファインセラミックス粒子と光学的特性 の異なる銅粒子に加え，ポリスチレンラテックス粒子 およびアルミナ粒子を用いた。またバイモーダル試料 に対する本推定法の有効性を検討するため, 公称粒子 径が0.95と $3.20 \mu \mathrm{m}$ の単分散シリカ粒子を重量比で 6 对 4 に混合したものも用いた。Table 1に, これら試料 の $50 \%$ 径( 銅粒子の場合は粒子径範囲) と粒子屈折率を 示す。なおここで示した $50 \%$ 径および粒子径範囲は, カタログ值である。以下の報告では, 試料名をTable 1の略号にて示す。

実験に用いたレーザー回折・散乱法粒子径分布測定 装置は，国内製 2 機種(以下装置 $\mathrm{A}$ ，装置 $\mathrm{B}$ と表示) と, 国外製 2 機種(以下装置C, 装置 $\mathrm{D}$ と表示)の計 4 機種で ある。装置入力光学特性值は, 粒子屈折率に対応し実 数部と虚数部から成っており, 何れの装置も入力光学 特性值の実数部は可変である。一方虚数部は，装置 $\mathrm{B}$, Dがあらかじめ0に固定されているが, 装置 $\mathrm{A}, \mathrm{C}$ は可 変である。また前報と同様に測定結果の確からしさを 検証するため, 試料の光学的特性の影響を受けず，か つ単分散粒子の測定に対し精度の高い電気的検知带法

Table 1 Sample properties

\begin{tabular}{|c|c|c|c|}
\hline \multicolumn{2}{|c|}{ Sample } & $\begin{array}{c}\text { Particle size } \\
\text { (catalog value) } \\
(\mu \mathrm{m})\end{array}$ & $\begin{array}{c}\text { Refractive index } \\
\text { (wavelength }(\mathrm{nm})) \\
(-)\end{array}$ \\
\hline \multirow{3}{*}{ Alumina } & $\mathrm{AL}-1$ & 3.0 & \multirow{2}{*}{$1.76(589)^{5)}$} \\
\hline & $\mathrm{AL}-2$ & 1.8 & \\
\hline & $\mathrm{AL}-3$ & 0.6 & $1.73(588)^{* *}$ \\
\hline \multirow{3}{*}{ Copper } & $\mathrm{CO}-1$ & $4 \sim 8$ & \multirow{3}{*}{$0.27-3.24 i(620)^{5)}$} \\
\hline & $\mathrm{CO}-2$ & $0.8 \sim 1.5$ & \\
\hline & $\mathrm{CO}-3$ & $0.3 \sim 0.5$ & \\
\hline \multirow{3}{*}{ Polystyrene } & $\mathrm{PO}-1$ & 1.09 & \multirow{3}{*}{$1.59(-)^{6)}$} \\
\hline & $\mathrm{PO}-2$ & 0.778 & \\
\hline & $\mathrm{PO}-3$ & 0.605 & \\
\hline \multirow{3}{*}{$\begin{array}{l}\text { Mono } \\
\text { dispersed } \\
\text { silica }\end{array}$} & SI - 1 & 0.95 & \multirow{3}{*}{$1.45(588)^{* *}$} \\
\hline & & & \\
\hline & SI -2 & 3.20 & \\
\hline
\end{tabular}

*: Particle range of coppers and $50 \%$ diameter in other samples are shown in the catalog.

**: Measured value by liquid immersion method. 
による測定も行った。

粒子径分布測定の際の分散媒には, へキサメタりん 酸ナトリウム $500 \mathrm{ppm}$ 蒸留水溶液を用いた。但し 銅粒 子CO-1, $\mathrm{CO}-2$ を測定する場合のみ, 測定時に粒子 の沈降を防止するためエチレングリコールを用いた。 そのため光学特性值を装置に入力する際には, 粒子の 屈折率だけでなく, 各々の媒液の屈折率(蒸留水: $1.33^{5)}$, エチレングリコール $\left.: 1.43^{5)}\right)$ も考虑した。試 料は, 出力 $300 W の$ 超音波発振子を用いて分散し, 最 も細かい粒子径分布が得られる時間まで超音波を照射 した。濃度が数百ppmの慗濁液を機種ごとに調製し た後,これを装置適正濃度になるまで希釈槽に滴下 し, 粒子径分布を測定した。なお入力光学特性值を変 化させ, 粒子径分布を求める際には, 希釈溸濁液の入 れ替えは行わず, 同じ暞濁液を用い測定を行った。何 れの試料も調製後の㦟濁液は安定で, 凝集による粒子 径分布の経時変化は認められなかった。

\section{3. 実験結果および考察}

\section{1 入力光学特性值推定結果}

\section{1.1 金属粒子の場合}

粒子屈折率の虚数部が大きい試料の例として, 銅粉 を測定した結果をFig. 1示す。ここでは銅粉 $(\mathrm{CO}-2)$ の結果を一例として示す。銅の屈折率 $(0.27-3.24 i)^{5)}$ は, 実数部, 虚数部ともに今回の実験に用いた粒子径 分布測定装置において入力可能な光学特性值の範囲外 にあるため,ここでは実数部, 虚数部ともに銅の屈折 率に最も近い值を入力し粒子径分布を得た。Fig. 1 よ り粒子径が約 $2 \mu \mathrm{m}$ 以上の領域では, 機種間のばらつき は比較的小さいが, これ以下の領域では機種間の整合 性が悪いことが分かる。次に前報 ${ }^{1)}$ で提案した最適入 力光学特性值の推定法により, 入力光学特性値の実数

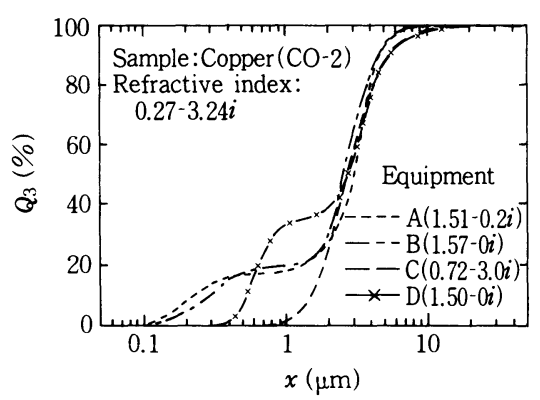

Fig. 1 Comparison of particle size distributions of copper which were measured by using the closest value to the described refractive index on the handbook
部の最適值を求めた結果を示す。その前に本推定法 ${ }^{1)}$ を簡単に説明しておく。まず入力光学特性值の虚数部 を 0 に固定し, 同一榡濁液に対して実数部を種々変化 させて, 粒子径分布を算出する。次に積算質量代表径 (ここでは $10 \%$ 径)と入力光学特性值との関係をプロッ トし，10\%径が最大となる光学特性值を選ぶ。それが 本推定法における最適入力光学特性值となる。ここで $10 \%$ 径を採用した理由は, 入力光学特性值の変化に対 する粒子径分布の変動が分布の微小粒子径側で現れや すく, 変動を検出しやすいためである。Fig. 2は装置 Cにおいて，虚数部を 0 に固定した場合の $10 \%$ 径と入 力光学特性值との関係をみたものであるが, 入力光学 特性值が 1.57 で10\%径が最大となった。Fig. 3は, 本 推定法に基づき $10 \%$ 径が最大值を示す入力光学特性值 で得た粒子径分布を各装置で比較した結果である。装 置A，B，Dにおいては，Fig. 1で見られた微小粒子側 の出力が消失し, 全粒子径範囲にわたり装置間の整合 性が向上した。装置Cにおいても本推定法で求めた最

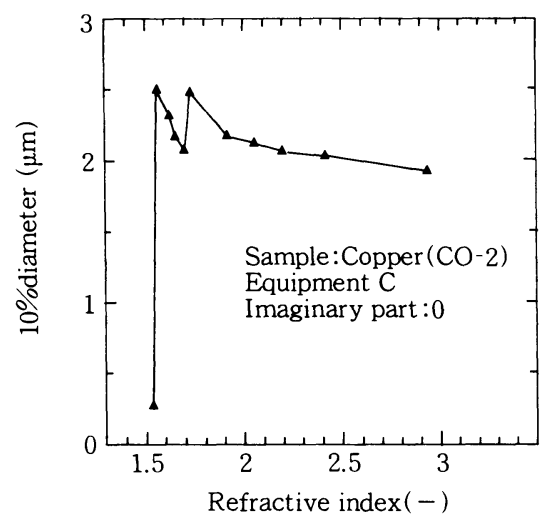

Fig. 2 Changes of $10 \%$ diameter by the difference of refractive index input value. The maximum value was indicated at 1.57

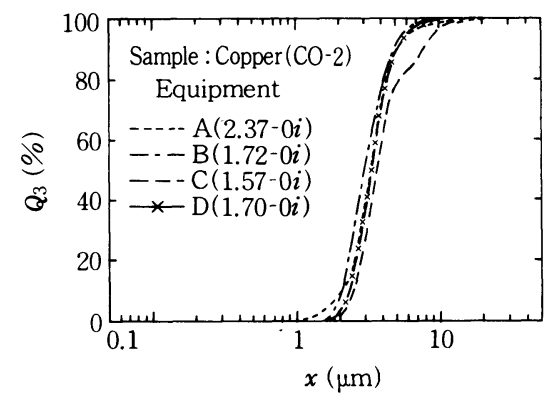

Fig. 3 Comparison of particle size distributions which were measured by the optimum input values of refractive index. The optimum values were estimated by fixing the imaginary part at 0 


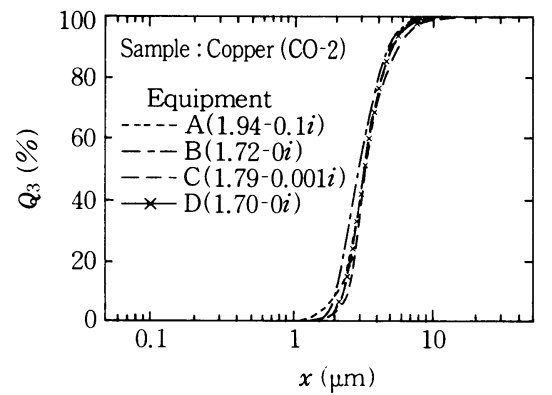

Fig. 4 Improvement of an agreement among four equipments. The optimum input values of refractive index of equipment $\mathrm{A}$ and $\mathrm{C}$ were estimated by changing both real and imaginary part

適値を用ると，分布の微小粒子径側では他の装置との 整合性が向上したが, 分布の大粒子径側では二峰性を 示すようになりFig. 1の結果に比べ装置間のばらつき が増大した。そこで次に届折率虚数部に関しても本法 を適用し, 入力可能な光学特性值の実数部および虚数 部をすべて変化させ，その中から10\%径が最大值を示 す光学特性值の組み合わせを選んだ後, 粒子径分布を 求めた。なおここでは, 入力光学特性值虚数部の変更 が可能な，装置 $\mathrm{A} ， \mathrm{C}$ 関してのみ検討を行った。そ の結果をFig. 4に示す。装置Cの大粒子径側の二峰性 は消え，全粒子径範囲にわたりすべての装置の分布が

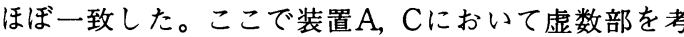
虑し求めた入力光学特性值の最適値と, Fig. 3の虚数 部を 0 とし求めた最適值では実数部の值が異なってい る。このことは入力光学特性值の実数部を, 虚数部 0 として得た最適值に固定して, 虚数部だけを変化させ るような方法では最適入力光学特性值を推定できず, 実数部および虚数部ともに変化させることで最適值が 推定できることを示している。次に入力光学特性值の 虚数部の影響を検討してみる。実数部の值をFig. 4に 示す最適值に固定し，虚数部を変え $10 \%$ 径の変化を見 た結果をFig. 5に示す。なお虚数部に設定可能な值

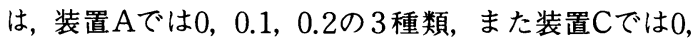
$0.001 ， 0.01 ， 0.1 の 4$ 種類である。10\%径が最大值を示

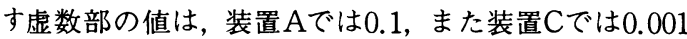
であり，虚数部 0 では最大值を示さなかった。また虚 数部の変化に伴う10\%径の変動の仕方は, 機種により 異なることが分かる。このようにレーザー回折・散乱 法では，実数部だけでなく虚数部の入力值によっても 分布が変動することが分かる。またここには示さない

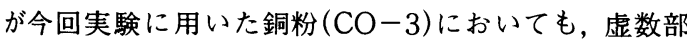

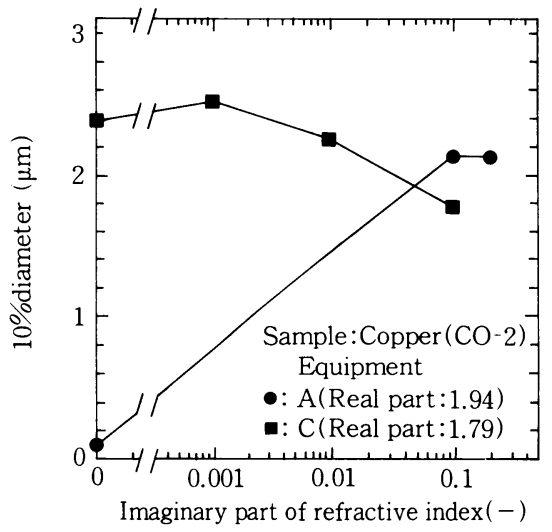

Fig. 5 The effect of imaginary part on $10 \%$ diameter in the case of copper. The maximum value of $10 \%$ diameter did not exist at the point of imaginary part 0 for each equipment

を 0 とした場合の最適入力光学特性值で求めた粒子径 分布は，銅の屈折率に最も近い入力值で求めた分布よ り，微小粒子径側での機種間のばらつきは減小するも のの, Fig. 3のように装置Cが分布の大粒子径側で二 峰性を示し，ばらつきが大きくなった。しかしながら 実数部だけでなく虚数部も考慮し推定を行うと，その ばらつきが消え各機種の整合性は向上するという銅粉 (CO-2) と同様の傾向を示した。

ここで，今回実験に用いた 3 種類の銅粒子につき， 虚数部を 0 と一定にした場合，およびすべての実数部 と虚数部を考虑した場合の二通りの推定法で求めた最 適入力光学特性值をTable 2に示した。前報のセラミ ックス粒子の結果と同様, 銅粉においても本推定法で 得た最適入力光学特性值の実数部の值は, 同じ材質で あっても測定試料および測定機種により異なることが 分かる。同様の事実は虚数部においても言える。銅粉 (CO-1)では, 実数部, 虚数部ともに考慮し推定して も，最適入力光学特性值は虚数部 0 で推定した結果と 同じになった。しかしながら，銅粉 $(\mathrm{CO}-2, \mathrm{CO}-3)$ では虚数部を考慮した場合の最適入力光学特性值の虚 数部は, 文献值に比べ非常に小さいが, 0 以外の值を 持つケースがあることから，金属粉では粒子屈折率虚 数部の影響が無視できない場合もあると考えられる。

以上の結果より，銅粉のように屈折率虚数部の大き い試料に関しては, 粒子屈折率虚数部が測定結果に及 ぼす影響が現われやすくなるが，本推定法において10 \%径が最大となる実数部と虚数部の組合せを選ぶこと で機種間の整合性が向上することが分かった。 
Table 2 Comparison of optimum input values of refractive index which were estimated by each method

\begin{tabular}{|c|c|c|c|c|c|}
\hline \multicolumn{2}{|c|}{ Sample } & \multirow{2}{*}{$\begin{array}{c}\text { Equipment } \\
\mathrm{A}\end{array}$} & \multirow{2}{*}{$\begin{array}{l}\text { Input value of refractive } \\
\text { index } \\
1.51-0.2 i\end{array}$} & \multirow{2}{*}{$\begin{array}{l}\text { Estimated value by } \\
\text { method } I^{*)} \\
1.56-0 i\end{array}$} & \multirow{2}{*}{$\begin{array}{l}\text { Estimated value by } \\
\text { method II*) } \\
1.56-0 i\end{array}$} \\
\hline \multirow{10}{*}{ Copper } & \multirow{3}{*}{$\mathrm{CO}-1$} & & & & \\
\hline & & B & $1.57-0 i$ & $1.86-0 i$ & - \\
\hline & & $\mathrm{C}$ & $0.72-3 i$ & $1.57-0 i$ & $1.57-0 i$ \\
\hline & \multirow{4}{*}{$\mathrm{CO}-2$} & $\mathrm{~A}$ & $1.51-0.2 i$ & $2.37-0 i$ & $1.94-0.1 i$ \\
\hline & & $\mathrm{B}$ & $1.57-0 i$ & $1.72-0 i$ & - \\
\hline & & $\mathrm{C}$ & $0.72-3 i$ & $1.57-0 i$ & $1.79-0.001 i$ \\
\hline & & $\mathrm{D}$ & $1.50-0 i$ & $1.70-0 i$ & - \\
\hline & \multirow{3}{*}{$\mathrm{CO}-3$} & A & $1.40-0.2 i$ & $2.80-0 i$ & $2.80-0 i$ \\
\hline & & $\mathrm{B}$ & $1.46-0 i$ & $3.06-0 i$ & - \\
\hline & & $\mathrm{C}$ & $0.67-3 i$ & $1.80-0 i$ & $2.00-0.01 i$ \\
\hline
\end{tabular}

* Method I : Imaginary part was fixed at 0 .

** Method II : Both real and imaginary part were changed

\section{1.2 樹脂粒子およびセラミックス粒子の 場合}

次に金属とは材質が異なり，屈折率の虚数部が非常 に小さいと言われる粒子に対しても，本推定法におけ る虚数部の影響を検討した。ここでは試料に単分散ポ リスチレンラテックス粒子およびアルミナ粒子を用い 検討した。Fig. 6は, ポリスチレンラテックス粒子 (PO-1)を, 文献值 (1.59)に近い光学特性值で測定し た結果である。ポリスチレンラテックスの消衰係数 は, 文献等に值が記載されていないことから,ここで は何れの装置にも設定可能な0とした。文献值による 測定では装置間の整合性が悪く，単分散粒子を測定し ているにもかかわらず機種によっては分布の幅が広く なっている。

Fig. 7は, 先の銅粉の結果と同様, 屈折率虚数部の 影響を考慮するため, 装置 $\mathrm{A}, \mathrm{C}$ においては，10\%径 が最大值を示す光学特性值を,すべての実数部と虚数 部の組み合せの中から選び，その值で求めた結果であ

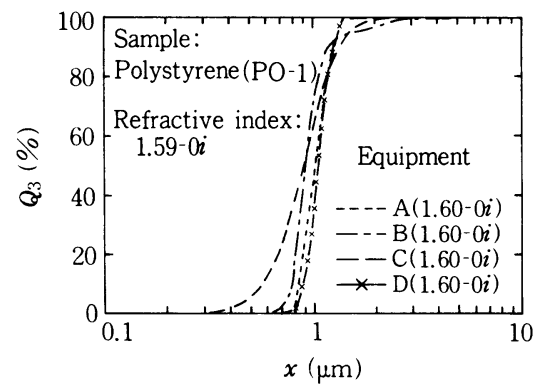

Fig. 6 Comparison of particle size distributions of polystyrene which were measured by using the closest value to the described refractive index on the handbook
る。また虚数部が $0 に$ 固定の装置 $\mathrm{B}, \mathrm{D}$ では実数部の み変化させ検討を行った。なお図中には電気的検知帯 法の測定結果も示す。本試料の場合, 装置Aでは虚数 部が 0 の場合に, 最適光学特性值が得られた。装置 Cでは2.74-0iおよび2.74-0.001iで10\%径が最大值を 示し, かつ各々の分布は一致した。文献值で求めた Fig. 6に比べ, 分布両端部で装置間のばらつきが減小 し，各機種ともによい単分散性を示すようになった。 またこの結果は電気的検知帯法の結果ともよく一致し た。

次に入力光学特性值の虚数部と, $10 \%$ 径との関係を 考察してみる。一例として, 実数部の值をFig. 7に示 す最適值に固定し，虚数部を変化させた場合の $10 \%$ 径 の変化をFig. 8に示す。装置Aでは，虚数部0で10\% 径が 0.845 と最大值を示し, 虚数部 0.1 で 0.841 とわずか に減小した。また更に虚数部を 0.2 にする， $10 \%$ 径 は急激に減小した。装置Cでは, 虚数部 0 および 0.001

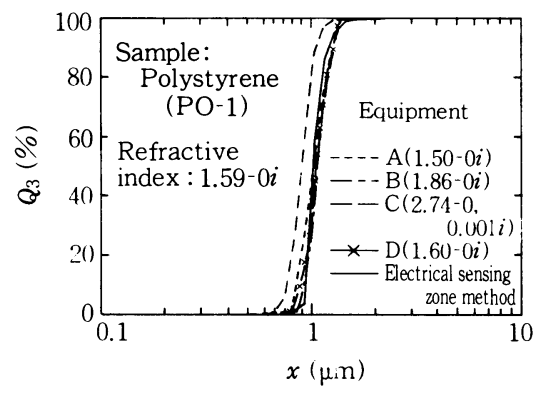

Fig. 7 Improvement of an agreement among four equipments. The optimum input values of refractive index of equipment $\mathrm{A}$ and $\mathrm{C}$ were estimated by changing both real and imaginary part 


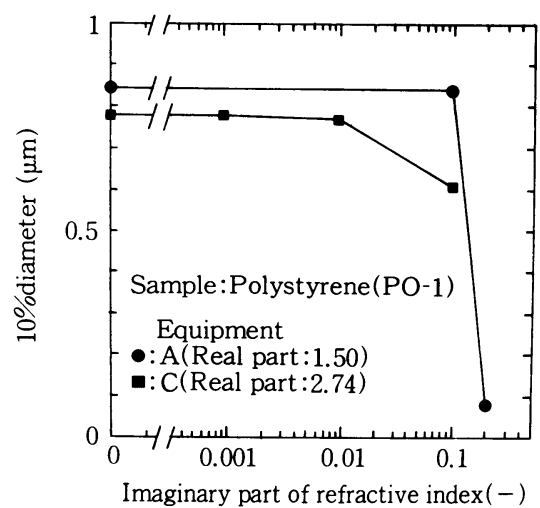

Fig. 8 The effect of imaginary part on $10 \%$ diameter in the case of polystyrene. The maximum value of $10 \%$ diameter existed at the point of imaginary part 0 for each equipment

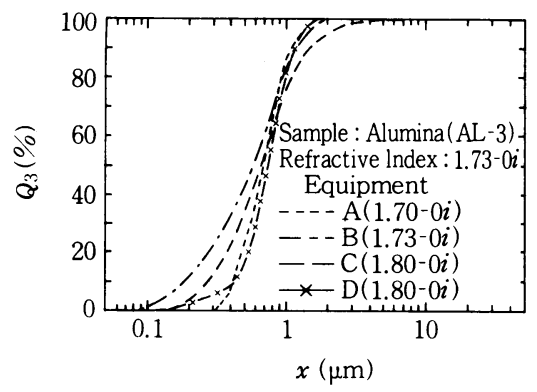

Fig. 9 Comparison of particle size distributions of alumina \#10000 which were measured by using the closest value to the measured refractive index

で最大値を示し，虚数部が増大するに伴い $10 \%$ 径は次 第に減小した。各装置とも，虚数部の值が大きくなる につれ，10\%径の変化が大きくなった。また実験に用 いた他のポリスチレンラテックス粒子(PO-2, PO-3)においても, 同様の傾向を示した。

次にアルミナ粒子の結果について示す。Fig. 9は, 試料 $(\mathrm{AL}-3)$ のアルミナ\#10000を，この試料の実測 屈折率(1.73)に近い光学特性值で測定した結果であ る。なおアルミナにおいてもポリスチレンラテックス と同様に消衰係数が不明なため,ここでは 0 とした。 図より分布の中心付近では，機種間の整合性は比較的 よいが，分布の両端部ではばらつきが大きくなった。

Fig. 10は先のポリスチレンラテックスの場合と同様 に, 入力光学特性值の実数部および虚数部を変えて推 定した結果である。アルミナにおいても装置Aでは虚 数部が 0 の時に，また装置Cでは $2.26-0 i$ おび $2.26-0.001 i$ の時に最適值が存在し, 各分布は一致し

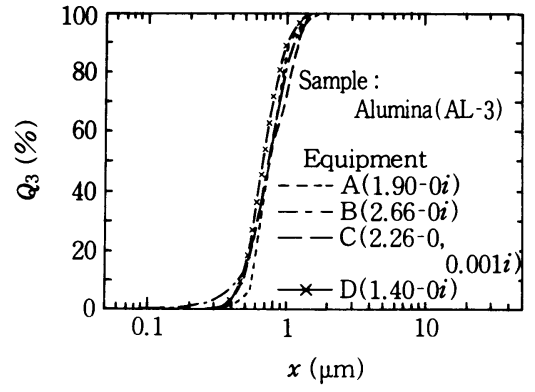

Fig. 10 Improvement of an agreement among four equipments. The optimum values of refractive index of equipment $\mathrm{A}$ and $\mathrm{C}$ were estimated by changing both real and imaginary part

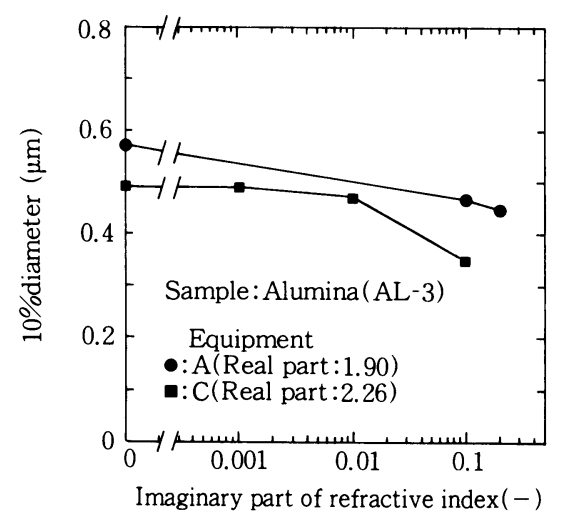

Fig. 11 The effect of imaginary part on $10 \%$ diameter in the case of alumina. The maximum value of $10 \%$ diameter existed at the point of imaginary part 0 for each equipment

た。これらの最適値を用いると，Fig. 9に見られた分 布两端部での機種間のばらつきが軽減され，装置間の 整合性が向上した。Fig. 11は，アルミナにおける虚 数部の影響を検討するため, Fig. 8と同様の整理を行 った結果である。本試料の場合も, 先のポリスチレン

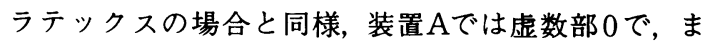
た装置Cでは虚数部が 0 および $0.001 て ゙ 10 \%$ 径が最大値 を示し, 虚数部の增大に伴い $10 \%$ 径が減小した。また この傾向は, 他のアルミナ粒子 $(\mathrm{AL}-2, \mathrm{AL}-3)$ の場 合にも同様に認められた。

Table 3は, ポリスチレンラテックスおよびアルミ ナにつき，本推定法を適用することにより求めた最適 入力光学特性值を示したものである。これら粒子の特 徵は, すべての装置が虚数部0で最適值を示す点であ る。また装置Cでは虚数部を考虑した場合, 試料によ つては虚数部 0 以外にも最適值を持つ場合があった。 この場合の $10 \%$ 径およびその最適值で求めた分布は, 
Table 3 Comparison of optimum input values of refractive index which were estimated by each method. The optimum values existed at the point of imaginary part 0 in all samples

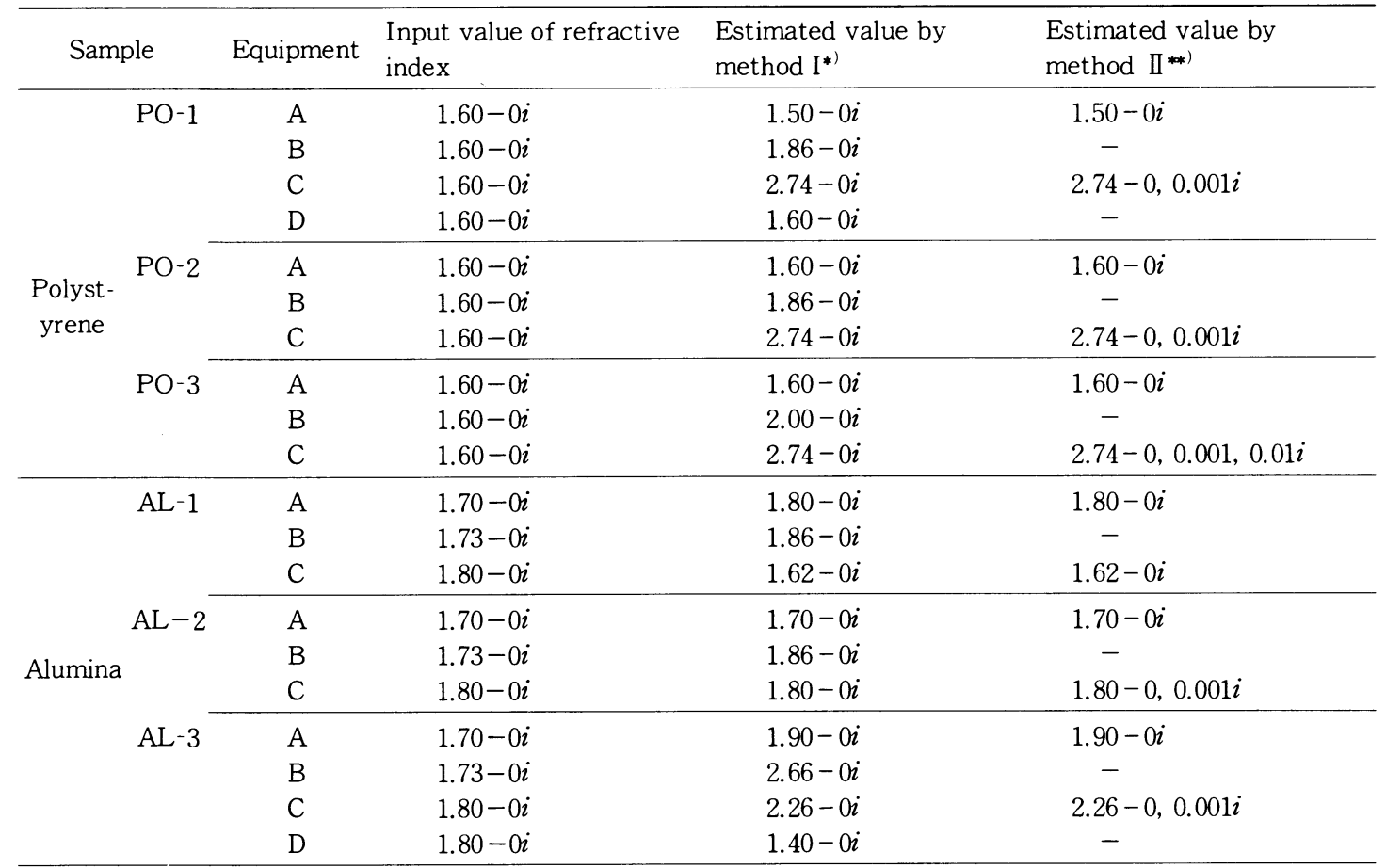

* Method I : Imaginary part was fixed at 0.

** Method II : Both real and imaginary part were changed.

虚数部 0 で求めたものに一致した。これらの粒子は屈 折率虚数部の值が小さいと考えられるため, 入力光学 特性值虚数部の影響も, 虚数部が 0 もしくはそれに近 い領域では現れにくいものと思われる。

以上より限られたサンプルからの結果ではあるが, 屈折率の虚数部が非常に小さいと見なせる材質の粒子 では, 最適入力光学特性值が虚数部 0 の場合に何れの 試料においても存在することから, 実用上は入力光学 特性值の虚数部を 0 として実数部のみ推定すればよい ことが分かった。

\section{2 パイモーダル試料測定に及ぼす入力光学特 性値の影響}

次にバイモーダル試料に対する本推定法の有効性に つき検討した。本実験では単分散シリカ粒子(SI-1 およびSI－2）を用いたので，ここでは入力光学特性值 の虚数部を 0 とした。入力光学特性値の実数部を変化 させた場合の粒子径分布の変動を，装置CにつきFig. 12に一例として示す。シリカの実測屈折率である 1.45 付近ではバイモーダル分布が現れたが, 入力光学特性 值が増大するに従いこのバイモーダル性は次第に消失 し単一分布を示すようになった。更に大きな值を入力

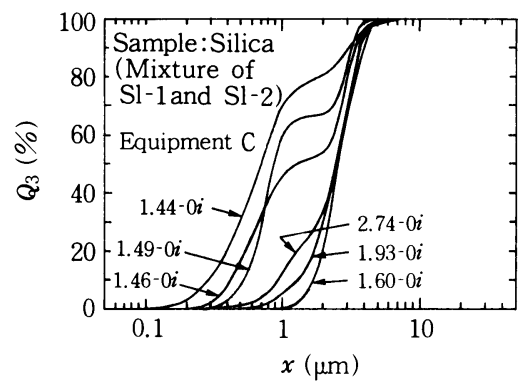

Fig. 12 The effect of refractive index input value on the result of measured particle size distribution of bimodal sample. The shape of the distribution changed remarkably. The bimodal shape of the distribution disappeared depending on the input value of refractive index

すると，微小粒子径側の分布が若干ではあるが細かい 方に再び移行した。このようにバイモーダル試料の測 定では, 入力光学特性值の変化に伴い分布の形状が大 きく変化する。ここでは装置Cの結果についてのみ示

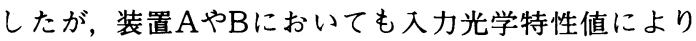
分布が大きく変化し，バイモーダル性が消えるという 同様の傾向を示した。Fig. 13は, シリカの実測屈折 


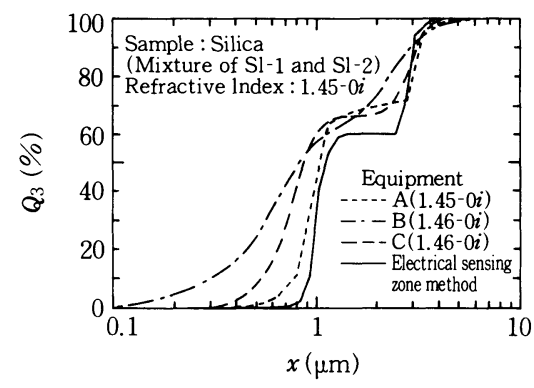

Fig. 13 Comparison of particle size distributions of silica bimodal sample which were measured by using the closest value to the measured refractive index

率，またはそれに近い值で求めた粒子径分布を各機種 において比較した結果である。また図中の実線は, 電 気的検知带法で実測した各々の単分散シリカ粒子の粒 子径分布を基に,小さい粒子と大きい粒子の重量比が6 对4となるように算出した分布である。いずれの装置 においてもバイモーダル分布は認められるものの, 分 布幅が狭く明暸なバイモーダル性を示す電気的検知带 法の結果とは一致しなかった。また分布の小粒子径側 では機種間の整合性も悪いことが分かる。このように レーザー回折・散乱法ではバイモーダル試料において も，実測屈折率を用い，精度よく測定することは難し いものと考えられる。次に本推定法を適用し求めた各 機種の分布をFig. 14示す。10\%径が最大值を示す入 力光学特性值にて求めた分布においては, いずれの機 種もバイモーダル分布は得られず，単一分布を示す結 果となった。

以上のことからバイモーダル試料においては, 本推 定法を適用しても, 測定精度の向上は望めないことが 分かった。前報1で報告したように, 単分散粒子や分 布に幅を持つ試料に関しては, 本法を適用すると機種 間のばらつきが減小したが, 本試料のようにバイモー タルで, かつ分布幅の狭いサンプルには, 本法の適用

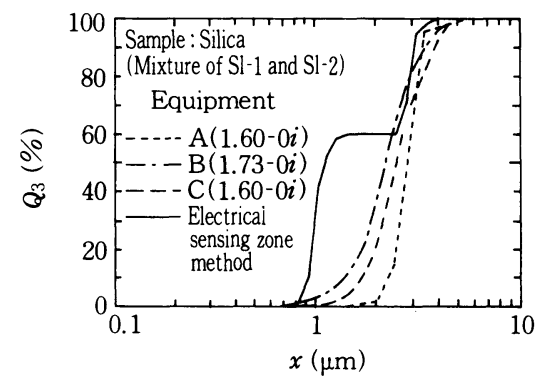

Fig. 14 The particle size distributions measured by optimum input values of refractive index. The accurate data was not obtained even applying the estimation method for bimodal sample

は不適切であると思われる。

\section{4. 結}

(1)金属粉等の粒子屈折率虚数部の值が大きい物質 に対しては, 入力光学特性值の実数部に加えて虚数部 も考虑し10\%径が最大值を示す組合せを選ぶことで, 機種間の整合性が向上した。

（2）樹脂, 酸化物のように屈折率の虚数部が非常に 小さい $\left(10^{-3}\right.$ 程度以下) 粒子に対しては, 入力光学特性 值の虚数部を 0 とし, $10 \%$ 径が最大となる実数部を推 定することにより機種間の整合性が向上した。

（3）レーザー回折・散乱法でバイモーダル試料を測 定する場合, 入力光学特性值の変化に伴い分布の形状 が大きく変化した。バイモーダル試料に対しては, 本 推定法の適用に限界があることが分かった。

[謝辞〕本研究に対し有益なるご助言を頂いた航 空宇宙技術研究所熱流体力学部反応流体研究室長 林 茂氏に謝意を表する。さらに粒子径分布の測定にあた っては, ホソカワミクロン(株) ·っくば粉体技術開発 センターにご協力を頂いたので,ここに記して謝意を 表する。

\section{References}

1) Hayakawa, O., K. Nakahira and J. Tsubaki : $J$. Soc. Powder Tech. Japan, 30, 652(1993)

2) MILTON KERKER : "The Scattering of Light and other electromagnetic radiation", p.13 Academic Press(1969)

3) Craig F. Bohren and Donald R.Huffman :

"Absorption and Scattering of Light by Small
Particles", p.279, John Wiley \& Sons(1983)

4) Malvern Instruments Ltd : "MasterSizer User Manual", Section 4. 14(1988)

5) CRC Press: "Handbook of Chemistry and Physics, 68th. ed.", (1987 1988)

6) Malvern Instruments Ltd : "INDEX for the Assistance of MasterSizer Users", (1990) 